\title{
Variation and ontogenetic changes of opercular paleae in a population of Sabellaria spinulosa (Polychaeta: Sabellaridae) from the South Adriatic Sea, with remarks on larval development
}

\author{
Marco Lezzi $^{1}$, Frine Cardone ${ }^{2}$, Barbara Mikac ${ }^{3}$, Adriana Giangrande ${ }^{1}$ \\ ${ }^{1}$ DiSTeBA University of Salento, CoNISMa, Via Provinciale Lecce- Monteroni, 73100 Lecce, Italy. \\ E-mail: adriana.giangrande@unisalento.it \\ ${ }^{2}$ Department of Zoology, Via Orabona 4, 70125 University of Bari, Italy. \\ ${ }^{3}$ Center for Marine Research, Ruđer Boković Institute, Giordano Paliaga 5, 52210 Rovinj, Croatia.
}

\begin{abstract}
Summary: Sabellaria alcocki Gravier, 1906, described for the Indian Ocean, should not be present in the Mediterranean area. Though S. spinulosa alcocki, a Mediterranean variety, can be well-distinguished from $S$. alcocki, it has recently been referred to as $S$. alcocki. Thus, S. alcocki appears in the Italian coast checklist. The recent finding of S. spinulosa reefs along the southern Adriatic coast, the first report of these biogenic constructions in the Mediterranean area, allowed us to compare its morphological variability with that of S. alcocki. A morphometric analysis of the opercular paleae showed a great deal of intrapopulation, size-independent variation, which cannot justify the existence of varieties within S. spinulosa. Moreover, the analysis of post-settlement development showed that opercular features change during individual growth. Recently settled individuals resemble $S$. alcocki, while the more advanced life stages become closer to $S$. spinulosa. Accordingly, we hypothesize that part of the erroneous Mediterranean records of $S$. alcocki could correspond to specimens of S. spinulosa at different stages of development.
\end{abstract}

Keywords: Annelida; Sabellariidae; Mediterranean; Adriatic; morphometry; development.

Variación y cambios ontogenéticos de paleae opercular en una población de Sabellaria spinulosa (Polychaeta: Sabellaridae) desde el mar Adriático del sur, con comentarios sobre el desarrollo larvario

Resumen: Sabellaria alcocki Gravier, 1906, descrita en el Océano Índico, no debería estar presente en el Mediterráneo. A pesar de que S. spinulosa alcocki, una variedad mediterránea, es fácilmente diferenciable de $S$. alcocki, esta especie ha sido recientemente citada como $S$. alcocki. Como consecuencia, esta última aparece en la lista faunística de las costas italianas. El reciente hallazgo de arrecifes de $S$. spinulosa en el sur del Adriático, la primera cita de estas formaciones biogénicas en el Mediterráneo, ha permitido comparar su variabilidad morfológica con la de S. alcocki. El análisis morfométrico de las características de las paleas operculares mostró una gran variabilidad intrapoblacional, independiente de la talla, lo cual no justifica la existencia de variedades en $S$. spinulosa. Por otro lado, el análisis del desarrollo post-asentamiento mostró que las características operculares cambian con el crecimiento individual. Los individuos recién asentados son más similares a $S$. alcocki, mientras que se asemejan más a S. spinulosa en etapas posteriores. Así pues se sugiere que una parte de los registros erróneos de S. alcocki en el Mediterráneo podrían corresponder a especímenes de S. spinulosa en diferentes etapas de desarrollo.

Palabras clave: Annelida; Sabellariidae; Mediterráneo; Adriático; morfometría; desarrollo.

Citation/Como citar este artículo: Lezzi M., Cardone F., Mikac B., Giangrande A. 2015. Variation and ontogenetic changes of opercular paleae in a population of Sabellaria spinulosa (Polychaeta: Sabellaridae) from the South Adriatic Sea, with remarks on larval development. Sci. Mar. 79(1): 137-150. doi: http://dx.doi.org/10.3989/scimar.04127.19A

Editor: D. Martin.

Received: July 16, 2014. Accepted: February 11, 2015. Published: February 23, 2015.

Copyright: () 2015 CSIC. This is an open-access article distributed under the Creative Commons Attribution-Non Commercial Lisence (by-nc) Spain 3.0.

\section{INTRODUCTION}

The genus Sabellaria (Annelida, Sabellariidae) includes at least 39 species worldwide (Kirtley 1994,
Nishi et al. 2010, Hutchings et al. 2012). As in all the sabellariid genera, the anterior part of the body shows a truncated surface forming an operculum used to seal the tube entrance to avoid desiccation and predation, 
and as a tool in shaping and arranging sand grains during tube construction (Eckelbarger 1975). Opercular features are of paramount taxonomic importance in Sabellariidae, but their taxonomy and phylogeny are not yet solved (Capa et al. 2012).

In Sabellaria, the operculum consists of three rows of chaetae called paleae. An outer row formed during ontogenesis by the pair of outer chaetigerous sacs, and middle and inner rows formed by inner chaetigerous sacs (Eckelbarger 1975). Opercular paleae can be highly variable in form and size, and their morphology is of particular interest in systematics because of the relative uniformity of other structures. However, the opercular paleae may show ontogenetic changes, with the "intermediate" forms of paleae differing from those of adult worms (Kirtley 1994). Moreover, the paleae can break and be altered by epifaunal growths and abrasion, increasing their morphological variability.

Three species of Sabellaria are currently known for the Mediterranean Sea: S. alveolata (Linnaeus, 1767), S. spinulosa (Leuckart, 1849), and S. alcocki Gravier, 1906 (Castelli et al. 2008). Sabellaria alveolata forms extensive long-lasting (4 to 9 years) intertidal biogenic reefs along most Atlantic European coasts (Wilson 1971, Achary 1974, Gruet 1982, 1986). Along the Italian coast, $S$. alveolata reefs occur in the Ligurian and the Tyrrhenian Sea (Dubois et al. 2002, La Porta and Nicoletti 2009).

Sabellaria spinulosa and S. alcocki are smaller than $S$. alveolata and inhabit the subtidal and lower intertidal/sublittoral fringes. Sabellaria spinulosa has been described from the North Sea (Leuckart 1849) and S. alcocki from the Indian Ocean (Gravier 1906). In Mediterranean areas, S. spinulosa occurs solitary or forming small clumps (Wilson 1970). By contrast, dense aggregations forming reefs up to $60 \mathrm{~cm}$ high and extending over several hectares can be found in areas with very high levels of suspended sediment in the North Sea (Wilson 1970, 1971) and around the British Isles (Pearce et al. 2011). Reefs may persist for many years, although individual clumps may be regularly formed and disintegrated (Jones et al. 2000). In fact, sabellarian reef structure and morphology are mainly influenced by currents, among other environmental conditions, with cyclical phases of construction and destruction (Gruet 1982, 1986, Porras et al. 1996, Dauvin 1997, Dubois et al. 2002).

Sabellaria spinulosa seems to be a fast growing annual form, which is able to quickly recolonize areas lost due to winter storms. Many thin crust-like structures formed by $S$. spinulosa probably correspond to these annual or transient constructions, but more stable communities have also been reported (Linke 1951). Sabellaria spinulosa shows a great deal of variability in the opercular features. There may be a single kind of middle paleae, alternate long and short, or several different lengths. The outer paleae are reported to have 2-3 teeth on the distal margin, with a plume bearing 5 to 12 denticles on each side. By contrast, the middle paleae in $S$. alcocki are all geniculate and have a long distally erect blade, while the outer paleae have three distal teeth and a long plume with up to 18-20 denticles on each side. Sabellaria spinulosa and S. alcocki are also distinguished by the absence of nuchal spines in the latter (Kirtley 1994).

Although $S$. alcocki has been considered as exclusive of the Indian Ocean (Nishi et al. 2010, Hutchings et al. 2012) and has not been reported in the Mediterranean Sea (Coll et al. 2010), the species was included in the checklist of the Italian coast (Castelli et al. 2008) and continues to be reported in Mediterranean faunistic papers (Parapar et al. 1992, Çinar et al. 2006, 2008). As a consequence, the geographical distribution of $S$. spinulosa and $S$. alcocki remains unclear (Read 2014). This is probably due to the above-mentioned high morphological variability of S. spinulosa. Fauvel (1914) considered S. alcocki as one of the varieties of $S$. spinulosa summarized in Fauvel (1927). Accordingly, S. spinulosa var. alcocki differs from $S$. spinulosa in having the middle opercular paleae with alternating long and short falciform blades. However, no mention of nuchal spines ("soies aciculaires" sensu Fauvel 1927) is present in Fauvel's description of S. spinulosa var. alcocki. Following Fauvel (1927), "S. spinulosa alcocki" has been reported worldwide (e.g. Kirtley 1994, Fauchald and Bellan 2013). More recently, however, S. alcocki started again to be reported as a separate species, leading to several erroneous reports around the world (e.g. Hartman 1944, Achary 1974, Fauchald 1977), including the Mediterranean coast (Parapar et al. 1992, Castelli et al. 2008, Çinar et al. 2006, 2008).

Within the framework of a multidisciplinary project on the functional and ecological role of marine bioconstructions, large biogenic formations of S. spinulosa were found along the Adriatic coast, offering an opportunity to examine the opercular variability of this species. In the present paper, we report the analyses of this variability in adults, coupled with a laboratory study on larval development to describe changes during the opercular formation. As mentioned above, the opercular paleae undergo ontogenetic changes in shape (Eckelbarger 1975). Also, during the development of S. spinulosa, the "primary paleae" are lost and replaced by "secondary paleae" progressively resembling the outer opercular paleae of the adult (Wilson 1929, 1970). Such a loss and progressive formation of the opercular paleae in post-settlement stages has only been reported for $S$. vulgaris Verril, 1873, although the size required to reach the stage having the adult paleae was not defined.

Taking into account that the development of $S$. spinulosa refers to populations from northern latitudes (Wilson 1929, 1970), we present herein the first ones for a Mediterranean population.

\section{MATERIALS AND METHODS}

\section{Sampling site}

Sabellaria spinulosa forms reef-like structures along the Adriatic coast, from Ancona to Gargano (Italy, southern Adriatic Sea) (Unpublished data). Within this area, samples were collected at Torre Mileto, Gar- 

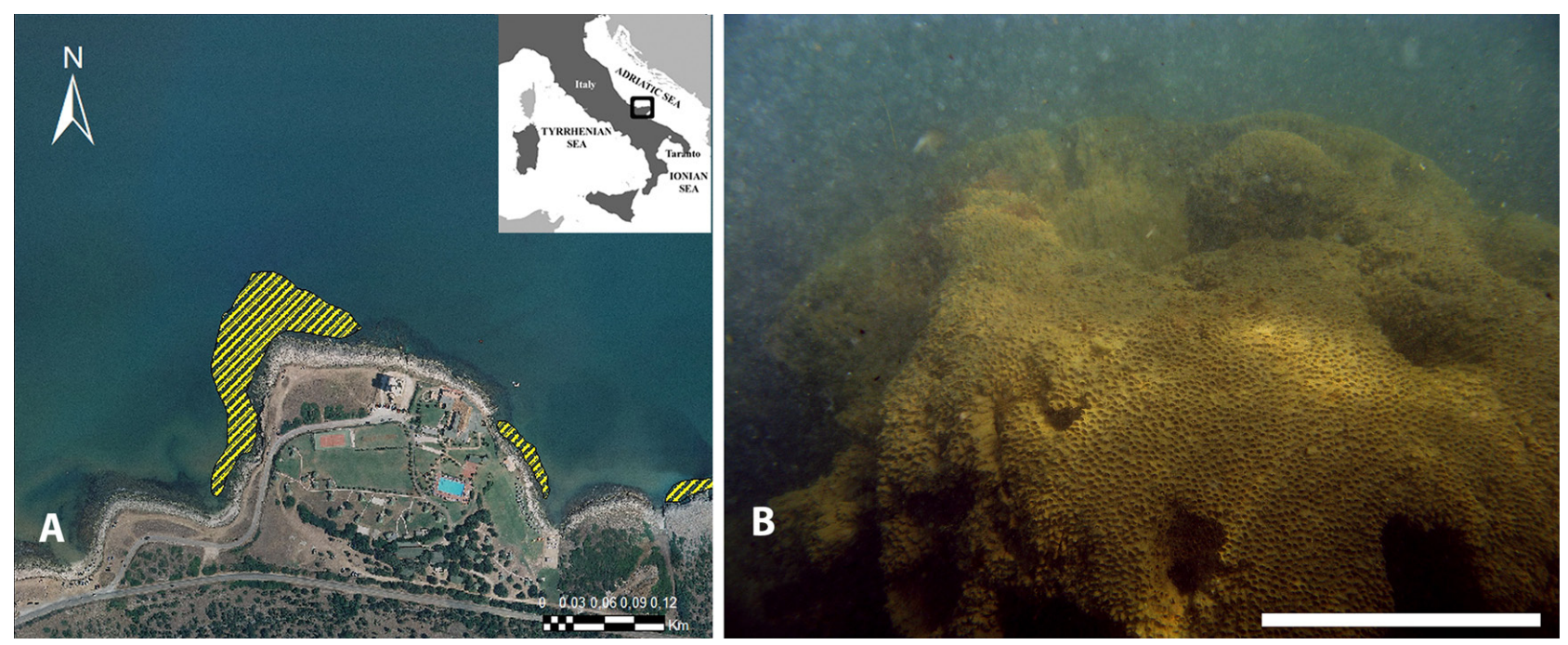

Fig. 1. - Sabellaria spinulosa sampling site at Torre Mileto (Gargano, southern Adriatic Sea). A, map of the study site; B, underwater photo from a reef; scale bar $60 \mathrm{~cm}$.

gano (Fig. 1A, B), where subtidal bioconstructions are highly developed from 1 to $2 \mathrm{~m}$ depth.

\section{Sampling procedures, population study and mor- phometry}

The sampled reef was located at $2 \mathrm{~m}$ depth and represented the largest biogenic formation in the area, with a maximum development in spring. Specimens were collected by scuba divers in $20 \times 20$ clusters of tubes in April 2012, October 2012, April 2013 and October 2013. The tubes were fixed in $4 \%$ formaldehyde and transported to the laboratory, where the worms were extracted and fixed in 70\% alcohol.

Size (length in $\mathrm{mm}$ ) and reproductive status were estimated on 50 worms for each sampling time, while the opercular features (i.e. maximum width of the outer paleae; number of denticles of the plume of the outer paleae; length of the blades in the middle paleae on at least 10 paleae for each specimen) were estimated for 20 specimens in April and October 2012 and in April and October 2013. The relationship between blade and shaft lengths (Fig. 2G) and the relationship between opercular features and worm size was estimated. The coefficient of variation was used to describe the variation in blade length of the middle paleae for each specimen: high coefficients indicate dissimilar blades, with a maximum when long and short alternate.

\section{Larval culture}

In April, June and October 2013 additional living specimens were collected and used to investigate reproduction and larval development. Sex in this species becomes distinguishable only at maturity: the abdominal segments in males were opaque white, while those of females were light pink. Sexually mature males and females were removed from their tubes and placed isolated in small petri dishes containing 0.45-um Millipore-filtered seawater at room temperature, where they quickly spawned. After one hour, fertilized eggs were transferred to clean petri dishes containing freshly filtered seawater and maintained at $14^{\circ} \mathrm{C}$ for 24 hours.

All free-swimming larvae were transferred to 1-L glass jars with filtered seawater. The jars were gently aerated with an aquarium air stone, which secondarily produced currents that helped to circulate food and larvae inside the jar. Cultures were covered with Parafilm to reduce salinity changes. Seawater was totally replaced twice a week. Larvae were fed with a culture of Isochrysis sp. at each water change. Twelve days after fertilization, a small quantity of sand from the adult tubes was added to the bottom of the jar culture for tube construction. At each water change, a few larvae and juvenile worms were removed from the culture for measurements and photographs. The development from fertilized eggs to trochophores was tracked on about one hundred eggs and larvae. Descriptions of later larval and juvenile stages are based on approximately 10 to 15 specimens at each observational time.

Two different cultures based on specimens collected in April 2013 were also set up and kept at $14^{\circ} \mathrm{C}$ and $21^{\circ} \mathrm{C}$, respectively.

Drawings were made with a camera lucida. Photographs were taken by an Axiocam ERC5S. All the materials are preserved in the author's collection at the Laboratory of Zoology of Salento University (PCZL).

\section{RESULTS}

The specimens were identified as S. spinulosa according to the shape of the middle paleae, the dentition pattern of the outer adult paleae, and the presence of nuchal spines, which allow them to be distinguished from S. alveolata and S. alcocki (Table 1).

A typical individual collected in October 2013 (Fig. 2) measured $10 \mathrm{~mm}$ in body length and had up to 25 abdominal segments (Fig. 2A, B). It has a medial organ with eyespots and 3-4 nuchal spines. Its posterior segments lack branchiae and the operculum is formed by 25-29 pairs of outer paleae (having a distal margin 
$140 \cdot$ M. Lezzi et al.

Table 1. - Main features of the three Mediterranean Sabellaria species, S. alveolata, S. spinulisa and S. alcocki, according to Hutchings et al. (2012)

\begin{tabular}{|c|c|c|c|c|c|c|c|c|c|c|}
\hline Species & $\begin{array}{l}\text { Type } \\
\text { locality }\end{array}$ & $\begin{array}{l}\text { Length exc. } \\
\text { cauda }(\mathrm{mm})\end{array}$ & $\begin{array}{l}\text { Max width } \\
\quad(\mathrm{mm})\end{array}$ & $\begin{array}{l}\text { Outer paleae } \\
\text { (pairs) }\end{array}$ & $\begin{array}{c}\text { Medial } \\
\text { plume on } \\
\text { outer paleae }\end{array}$ & $\begin{array}{c}\text { Teeth } \\
\text { on distal } \\
\text { margin of } \\
\text { outer paleae } \\
\text { (pairs) }\end{array}$ & $\begin{array}{l}\text { Middle } \\
\text { paleae } \\
\text { (pairs) }\end{array}$ & $\begin{array}{c}\text { Types of } \\
\text { middle } \\
\text { paleae }\end{array}$ & $\begin{array}{l}\text { Middle } \\
\text { paleae, } 1, \\
\text { long form }\end{array}$ & $\begin{array}{c}\text { Middle } \\
\text { paleae, } 2, \\
\text { short form }\end{array}$ \\
\hline S. aleveolata & British Isles & NA & NA & 36 & $\begin{array}{l}\text { Present, } \\
\text { smooth }\end{array}$ & 2-3, curved & 21 & 1 & $\begin{array}{c}\text { Twisted } \\
\text { blades }\end{array}$ & - \\
\hline S. spinulosa & Iceland & 25 & 2.5 & $25-29$ & $\begin{array}{c}\text { Present, 4-6 } \\
\text { denticles }\end{array}$ & $2-3$ & $10-12$ & 2 & $\begin{array}{l}\text { Long } \\
\text { extended } \\
\text { blunt tips }\end{array}$ & $\begin{array}{c}\text { Pointed } \\
\text { symmetrical } \\
\text { tips }\end{array}$ \\
\hline \multirow[t]{2}{*}{ S. alcocki } & $\begin{array}{l}\text { Indian } \\
\text { Ocean }\end{array}$ & 11.5 & 5 & 20 & $\begin{array}{c}\text { Present, } 20 \\
\text { denticles }\end{array}$ & 3 & 10 & 1 & $\begin{array}{c}\text { Elongate } \\
\text { with curved } \\
\text { blunt tips }\end{array}$ & - \\
\hline & $\begin{array}{l}\text { Inner paleae } \\
\text { (pairs) }\end{array}$ & \multicolumn{2}{|c|}{ Inner paleae (shape) } & $\begin{array}{c}\text { Eyespots } \\
\text { on median } \\
\text { organ }\end{array}$ & $\begin{array}{l}\text { Opercular } \\
\text { papillae } \\
\text { (pairs) }\end{array}$ & $\begin{array}{l}\text { Nuchal } \\
\text { spines } \\
\text { (pairs) }\end{array}$ & $\begin{array}{l}\text { Neuroch } \\
\text { seg. } 1\end{array}$ & $\begin{array}{c}\text { Median } \\
\text { organ }\end{array}$ & $\begin{array}{l}\text { Lateral lobes } \\
\text { seg. } 2 \text { (pairs) }\end{array}$ & $\begin{array}{c}\text { Branchiae, } \\
\text { posterior } \\
\text { segments }\end{array}$ \\
\hline S. aleveolata & 17 & \multicolumn{2}{|c|}{ Short blunt tips } & Present & $8-10$ & Absent & Present & Present & 1 & Absent \\
\hline S. spinulosa & $10-12$ & \multicolumn{2}{|c|}{$\begin{array}{l}\text { Asymmetrical twisted } \\
\text { blades with blunt tips }\end{array}$} & Present & Present & $3-4$ & Present & Present & NA & Absent \\
\hline S. alcocki & 10 & \multicolumn{2}{|c|}{ Elongate blunt tips } & NA & Present & Absent & Present & Present & NA & Present \\
\hline
\end{tabular}

A
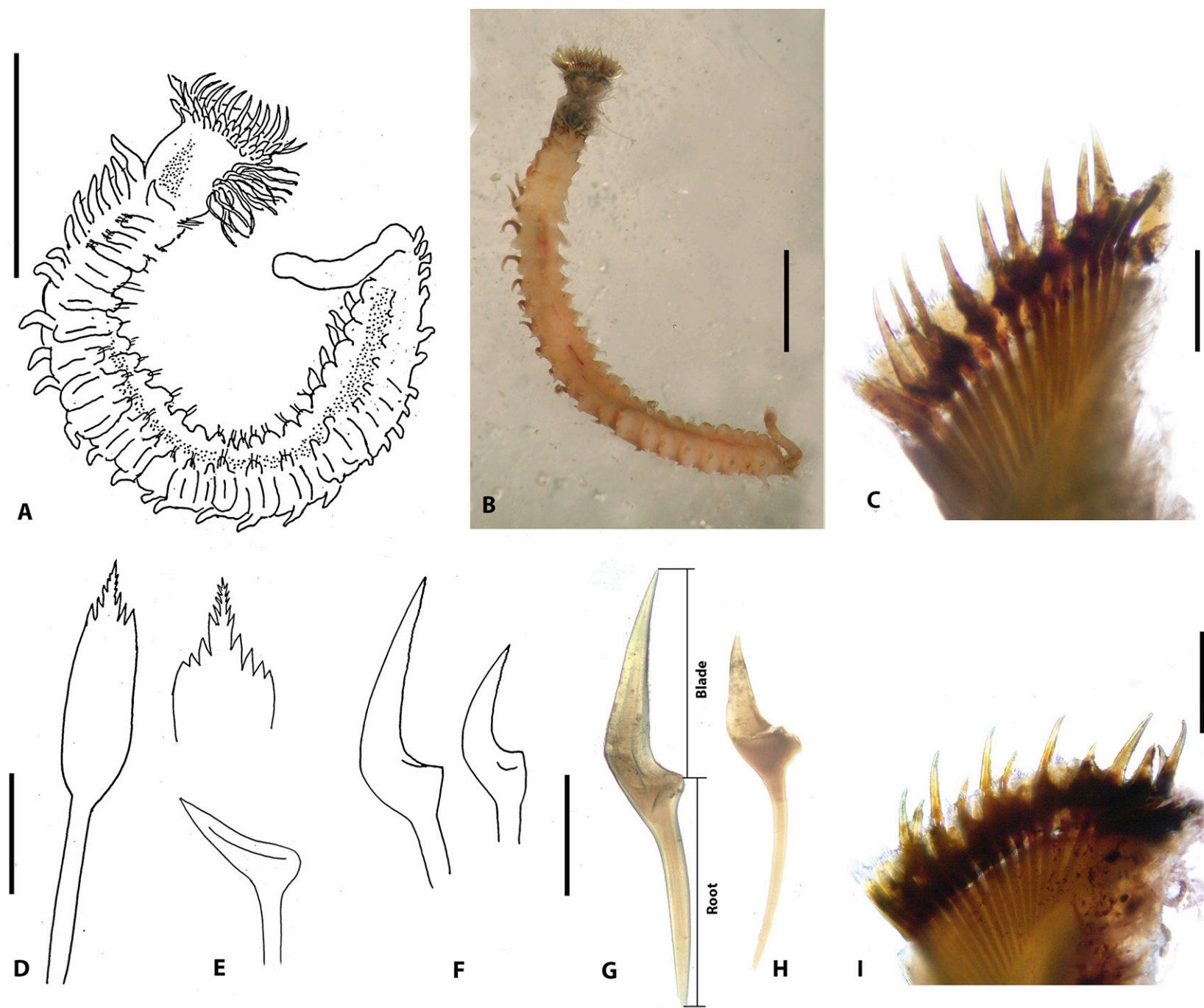

Fig. 2. - Sabellaria spinulosa. A-B, entire worm (scale bar $0.5 \mathrm{~cm}$ ); C, detail of the operculum of a specimen showing the homogeneous development in the blade of the middle paleae (scale bar $800 \mu \mathrm{m}$ ); D, outer palea, with a detail of the denticulate plume (scale bar $300 \mu \mathrm{m}$ ); E) inner paleae; F-H, middle paleae from different specimens (scale bar $300 \mathrm{um}$ ); I, detail of the operculum of a specimen with a different development of the blade (alternate long and short) in the middle palea row (scale bar $800 \mu \mathrm{m}$ ). 

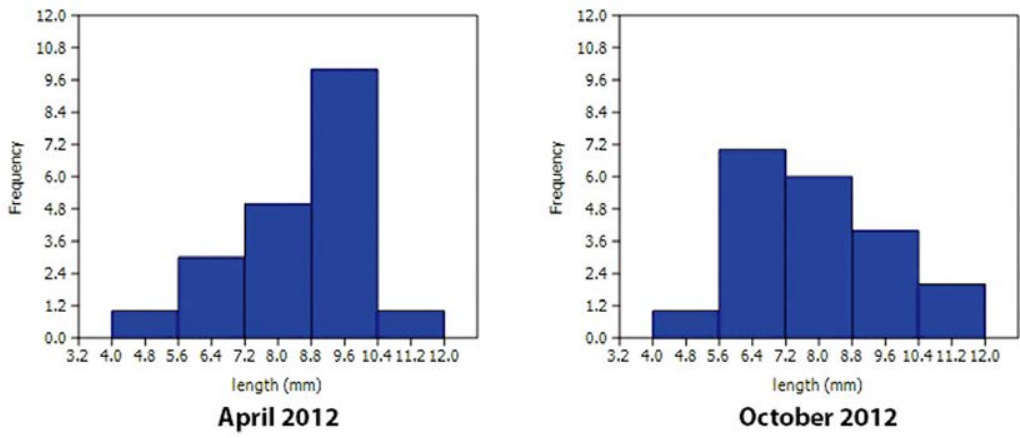

October 2012
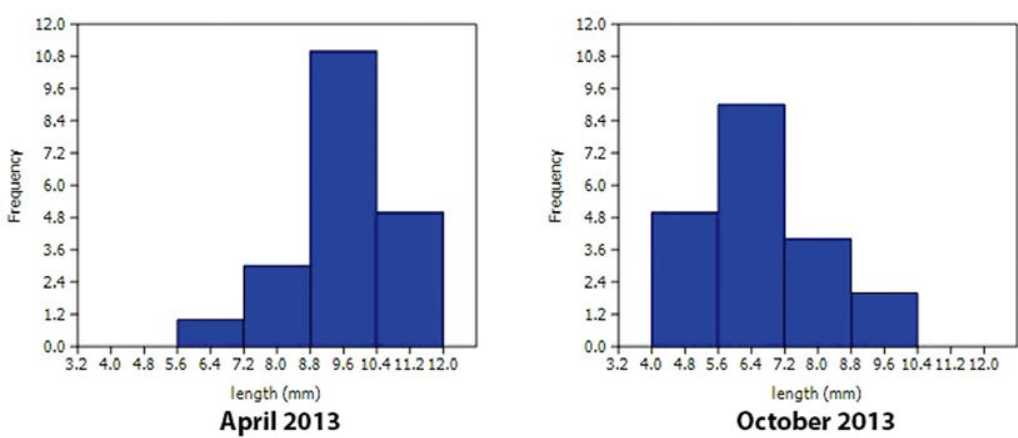

Fig. 3. - Sabellaria spinulosa. Size-frequency histograms.

with 2-4 teeth and a central denticulate plume with about 6 denticles on each side, Fig. 2D), 10-12 inner paleae (geniculate, with shallow excavate base on upper surface, Fig. 2E), and 10-12 middle paleae (slightly geniculate, with a variable distal blade and an excavate base, Fig. 2F, G).

\section{Observation on field population and morphometry}

October was characterized by smaller size individuals, especially in 2012 (Fig. 3, Table 2). In these months, about $30 \%$ of the individuals contained eggs at different stages of maturity, while in April 65\% of the specimens contained large eggs. This pattern was also present in the live sample from June 2013, in which a 3:2 sex ratio was estimated. In preserved samples it was not possible to identify males, so sex ratios could not be estimated.

The specimens from the field population measured 4 to $12 \mathrm{~mm}$ in body length. The number of denticles in the plume of the external paleae ranged from 6 to 12 . The pattern of blade length in the middle paleae was

Table 2. - Mean value \pm standard deviation of the measured body features of Sabellaria spinulosa specimens in the four collecting times

\begin{tabular}{lcccc}
\hline Sample & \multirow{2}{*}{ Worm size mm } & Width $\mu \mathrm{m}$ & $\begin{array}{c}\text { Outer paleae } \\
\text { Number of denticles }\end{array}$ & $\begin{array}{c}\text { Middle paleae } \\
\text { Coefficient of variation }\end{array}$ \\
\hline April 2012 & $8.5 \pm 1.7$ & $168.1 \pm 16.4$ & $9.1 \pm 1.7$ & $0.16 \pm 0.11$ \\
October 2012 & $8.0 \pm 1.5$ & $160.6 \pm 22.2$ & $9.9 \pm 1.6$ & $0.20 \pm 0.07$ \\
April 2013 & $9.6 \pm 1.2$ & $165.8 \pm 12.2$ & $9.6 \pm 1.5$ & $0.19 \pm 0.10$ \\
October 2013 & $6.5 \pm 1.5$ & $136.0 \pm 17$ & $9.0 \pm 1.7$ & $0.16 \pm 0.11$ \\
\hline
\end{tabular}
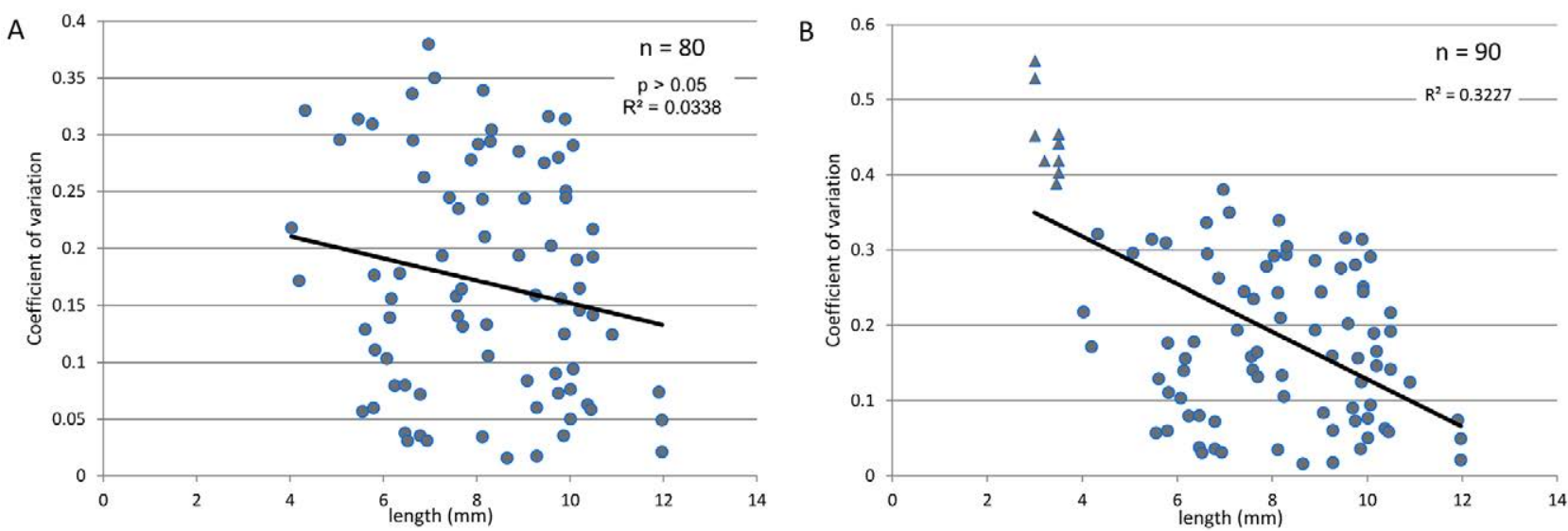

Fig. 4. - Sabellaria spinulosa. Relationship between coefficient of variation and worm length: A, field population; B, combined data from laboratory settlers and field data. 

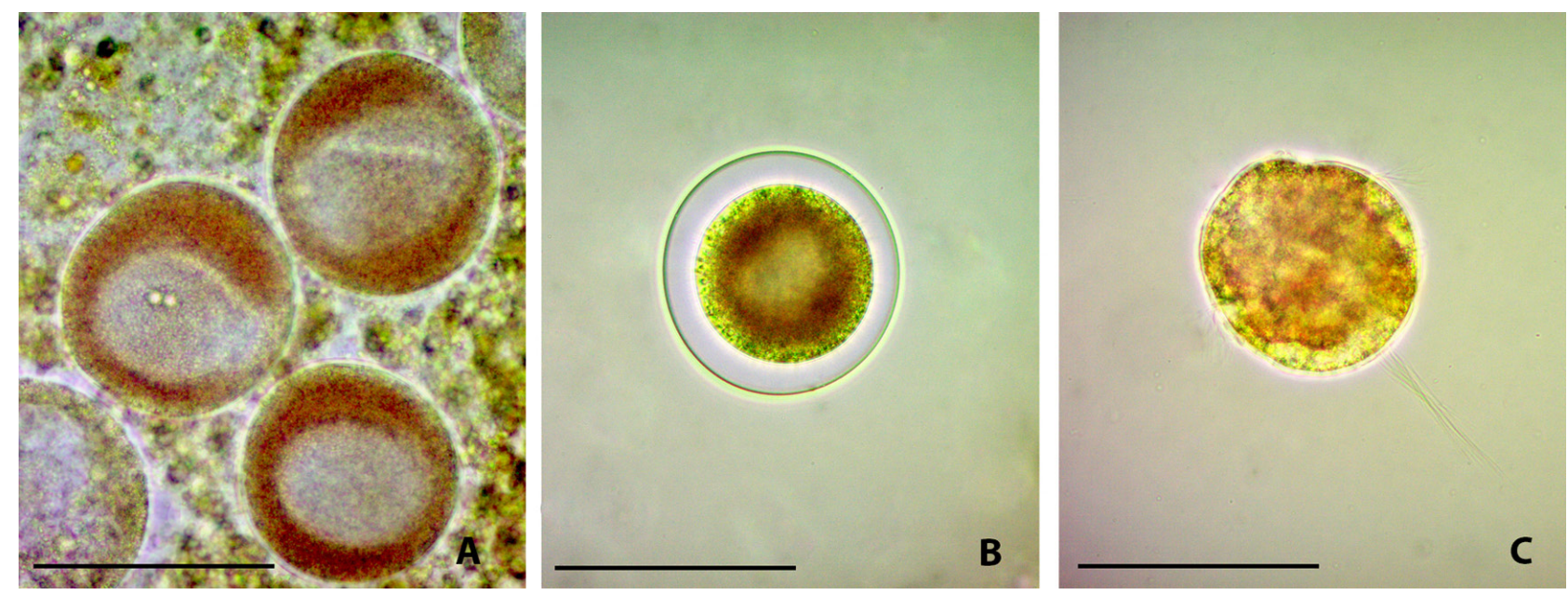

Fig. 5. - Sabellaria spinulosa. A, intracoelomic ocyte; B, fertilized egg; C, 48-hour trochophore. Scale bar $100 \mu \mathrm{m}$

very variable: some specimens had all blades long (Fig. $2 \mathrm{C}, \mathrm{G}$ ) or all short (Fig. 2H), while others had alternating long and short blades (Fig. 2H, I). The coefficient of variation ranged from 0.015 to 0.38 , and was higher in April 2012 (Table 2).

Only the width of the outer paleae was positively correlated to worm size $\left(\mathrm{r}^{2}=0.68 ; \mathrm{p}<0.01\right)$.

As for the middle paleae, about half the individuals had low coefficients of variation at each sampling time, except in April 2012 (90\%). The coefficient of variation was not correlated with worm size (either for the whole data set or for each individual sampling time), although there was a negative general trend (meaning that all blades tended to be long, not alternating long and short (Fig. 4A).

\section{Larval development and opercular ontogenetic changes}

Ripe specimens were found in each sampling period. Artificial fertilization was obtained in April, June and October 2013. However, the larvae from October 2013 did not complete their development.

The number of eggs per female in April and October 2013 was $34800 \pm 1300$ and $5500 \pm 1700$, respectively. In April 2013, the eggs measured about $90 \pm 3.3$ $u m$ in diameter.

About $100 \%$ of eggs were fertilized immediately after being exposed to sperm and trochophores were already observed two days later. Figure 5 shows eggs inside the coelom, a fertilized egg, and an early trochophore.

Pelagic larval development lasted for about two weeks (Fig. 6A-D). Larvae appeared identical to that described by Wilson (1929, 1970) for British waters, with long provisional chaetae and larval eyes located within the metatroch-prototroch area. During this period, larvae tended to swim fast, freely and random. Afterwards, larvae started to swim in aggregates, becoming almost benthic at about 20 days after fertilization (Fig. 6E). The last pre-metamorphosing larva measured about $300 \mu \mathrm{m}$ in length (Figs 6F, 7A) and had five distinct body regions: the episphere (with two pairs of dorsal reddish-black eyespots), two achaetiger- ous thoracic segments, three chaetigerous parathoracic segments, four abdominal segments with uncinigerous lobes, and the pygidium (Fig. 7A). At this stage, the metatroch-prototroch extended around the perimeter of the episphere, two tentacles were positioned towards the posterior end, and laterally there were two chaetal bundles containing several shorter settling chaetae obscured by the longer provisional chaetae (Fig. 7D). The notopodial bundles of each parathoracic segment bear two winged capillary chaetae and two curved capillary chaetae (Fig. 7E). Small neuropodial lobes appear ventrally on parathoracic and abdominal segments, each bearing two short hair-like capillary chaetae.

The most obvious change in the morphology of the metamorphosing larva is the anterior rotation of the dorsal tentacles (Fig. 7B). These structures are directed forward, parallel to the substrate. The episphere, now the prostomium, is restricted to the lateral area bounded by the base of the tentacles. The prototroch has been lost and the provisional chaetae are shed, exposing the shorter settling paleae (Fig. 7C).

The growth rate was faster at $21^{\circ} \mathrm{C}$ than at $14^{\circ} \mathrm{C}$ (Fig. 8). Differences are observed from 4 to 22 days after fertilization. Fifteen-day larvae reared at $14^{\circ} \mathrm{C}$ measured $220 \mu \mathrm{m}$ in length and were still pelagic, while they reached $300 \mu \mathrm{m}$ and started to become benthic when reared at $21^{\circ} \mathrm{C}$. However, in the treatments, growth seemed to stop from the $22^{\text {nd }}$ to $34^{\text {th }}$ day and settlement was observed after 34 days. At $14^{\circ} \mathrm{C}$, larvae metamorphosed after about 10 days from the start of the benthic stage, while at $20^{\circ} \mathrm{C}$ larvae delayed metamorphosis for a few more days.

At about the $22^{\text {nd }}$ day the larvae at $14^{\circ} \mathrm{C}$ became benthic and started to crawl and explore the bottom, searching for sand to build their tube. Although not measured during the pelagic phase, mortality seemed to be very low; by contrast, mortality reached about $90 \%$ after settlement.

Recruits constructed primary mucous tubes, spatially separated from one another. Most larvae settled and started to construct tubes within about 10 days after settling. At 15 days (45 days from fertilization), all larvae had already settled. 


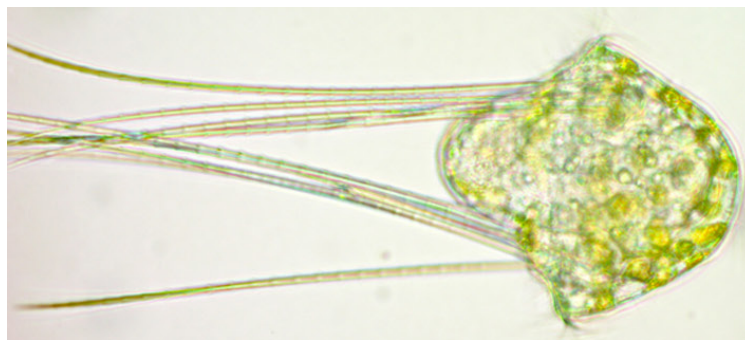

A
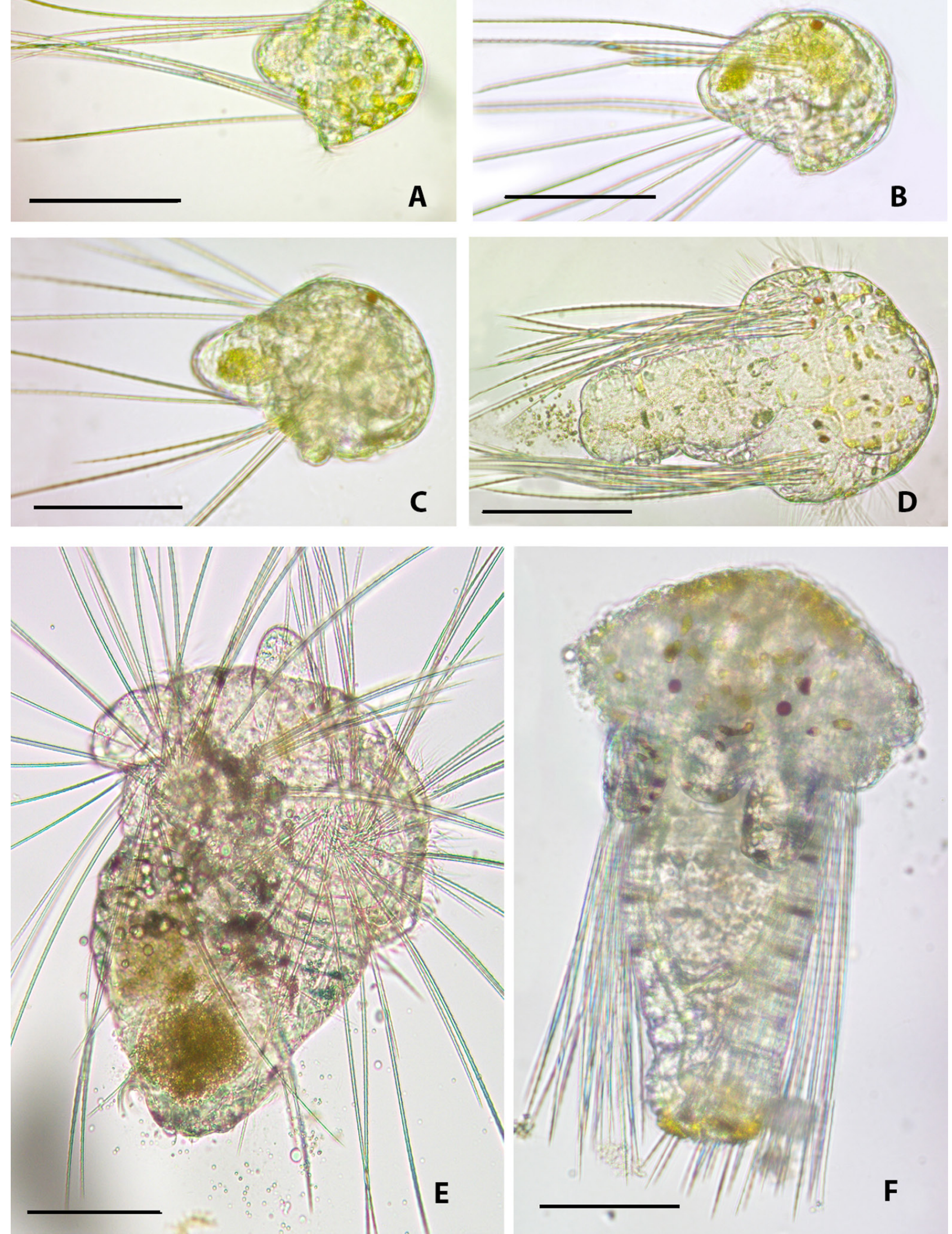

Fig. 6. - Sabellaria spinulosa. A, 5-day pelagic larva; B, 9-day pelagic larva; C, 13-day pelagic larva; D, 16-day pelagic larva; E, 20-day pelagic larva; F, 30-day larval (benthic) stage. Scale bar $100 \mu \mathrm{m}$. 


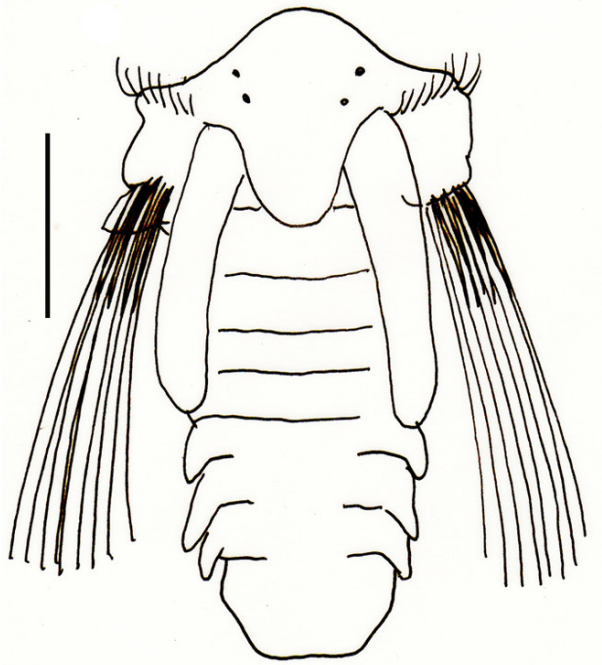

A

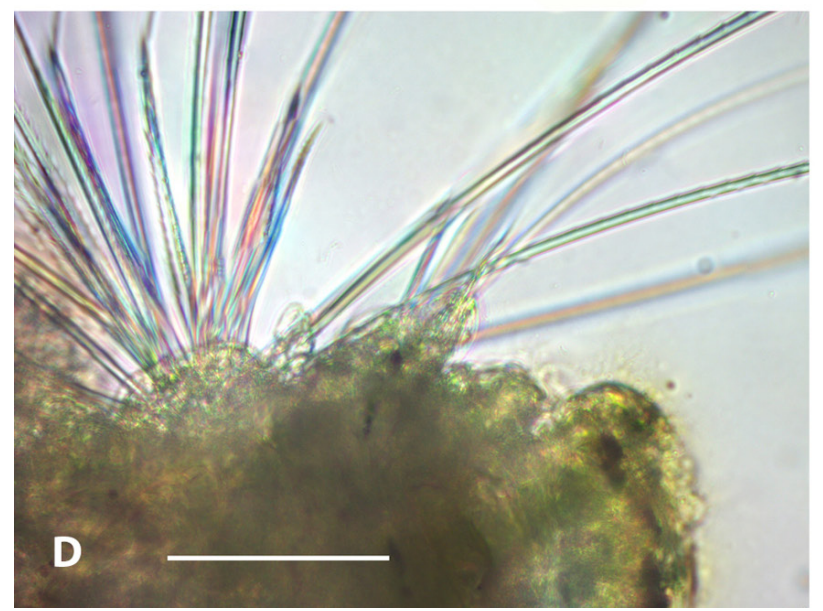

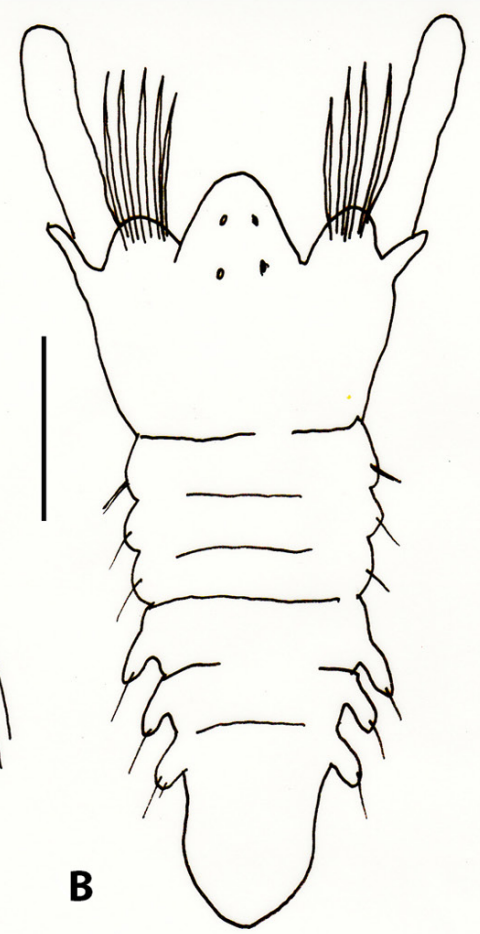

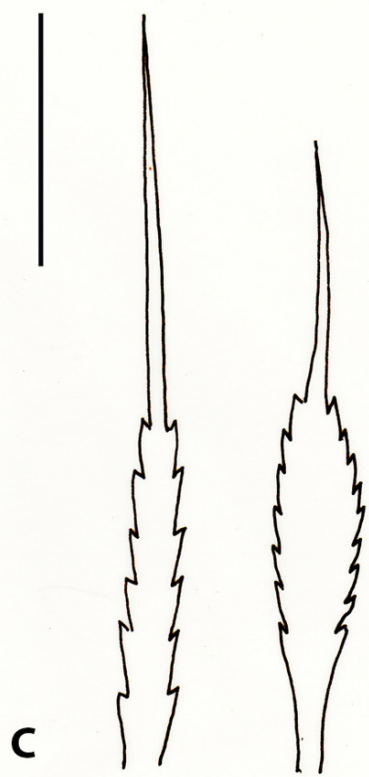

Fig. 7. - Sabellaria spinulosa. A, 30-day larval (benthic) stage (scale bar $100 \mu \mathrm{m}$ ); B, recently metamorphosed specimen (scale bar $100 \mu \mathrm{m}$ ); C, settling paleae from metamorphosed specimen (scale bar $20 \mu \mathrm{m}$ ); D, settling paleae within provisional chaetae (scale bar $100 \mu \mathrm{m}$ ); E, chaetae from a parathoracic segment (scale bar $50 \mu \mathrm{m}$ ).

Fifteen days after metamorphosis, the juveniles measured about $700 \mu \mathrm{m}$ in length and had two corrugated and ciliated tentacles (palps) (Fig. 9A, D). Settling paleae, which had rotated anteriorly and would form the outer paleae of the operculum, now became the primary paleae and initially appeared elongated (Fig. 9C). The juvenile has two rows of operculate paleae and two feeding tentacles. Three inner paleae, which become more similar to the inner paleae of the adult, and three middle paleae, appear on each side of the operculum (Fig. 9B, C, E, F). Anterior tentacles (palps) are used to collect sediment grains, while the paleae are used in manipulating them during the tube construction, so the area in front of the tube opening always appeared clean. At the same time, several additional small and thin feeding tentacles develop anteriorly. Two thoracic segments and three abdominal segments are differenti-

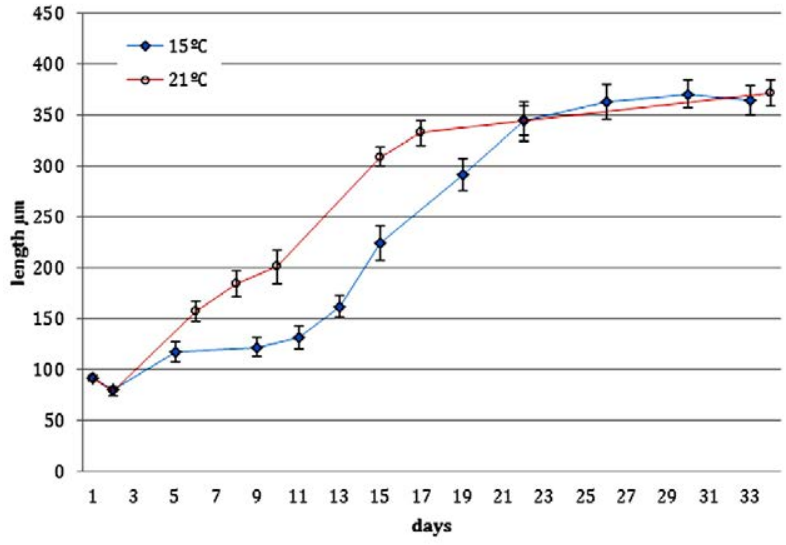

Fig. 8. - Sabellaria spinulosa. Larval growth rate at $15^{\circ} \mathrm{C}$ and $21^{\circ} \mathrm{C}$. 

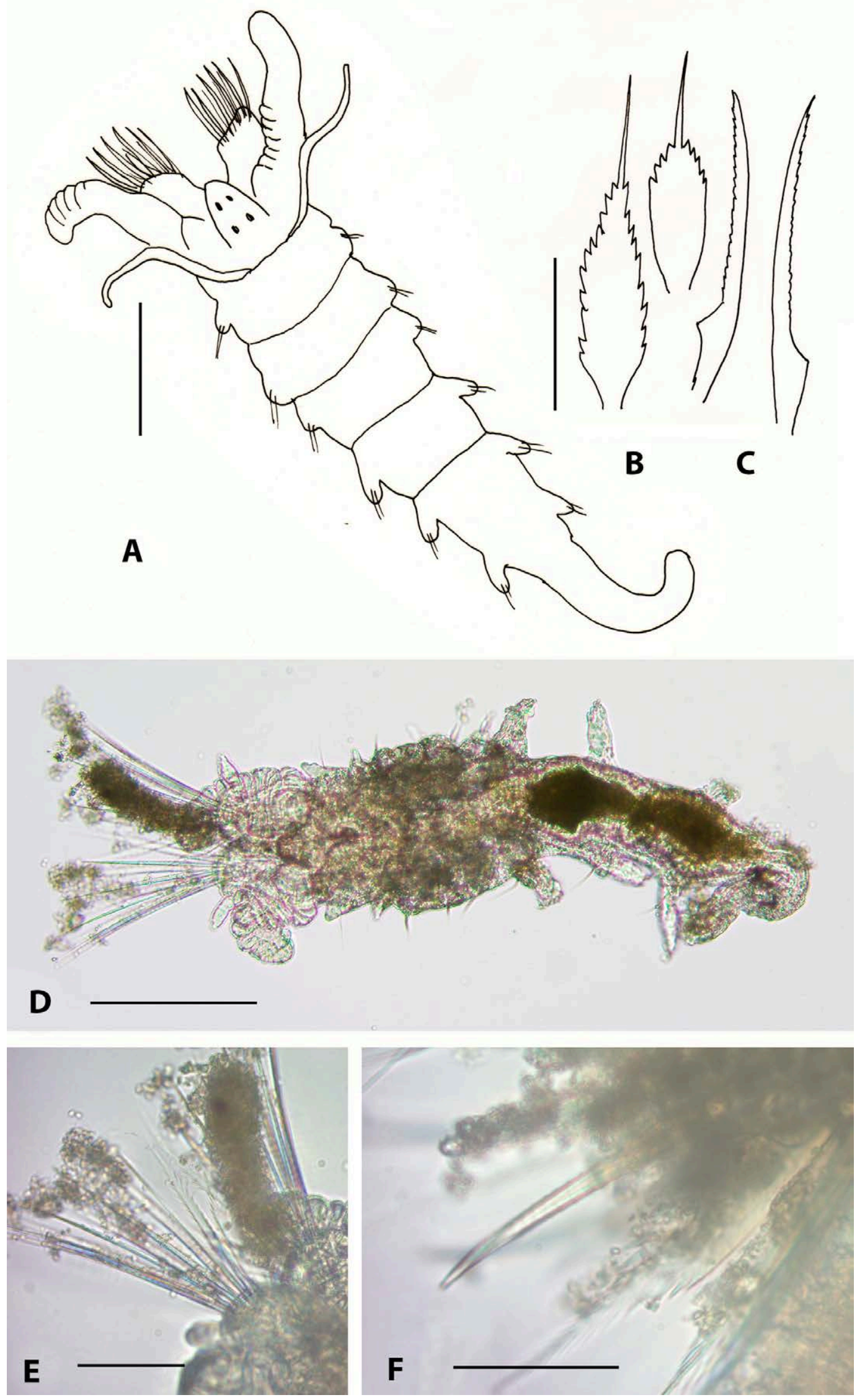

Fig. 9. - Sabellaria spinulosa. A, juvenile 15 days after metamorphosis (49 days after fertilization) (scale bar $200 \mu \mathrm{m}$ ); B, outer paleae (scale bar $100 \mathrm{um}$ ); C) middle paleae (scale bar $100 \mathrm{um}$ ); D, photo from 15 days after the juvenile metamorphosis (49 days after fertilization). (scale bar $200 \mu \mathrm{m}$ ); E, detail of the operculum showing the outer paleae (scale bar $100 \mu \mathrm{m}$ ); F, detail of a middle palea (scale bar $50 \mu \mathrm{m}$ ). 

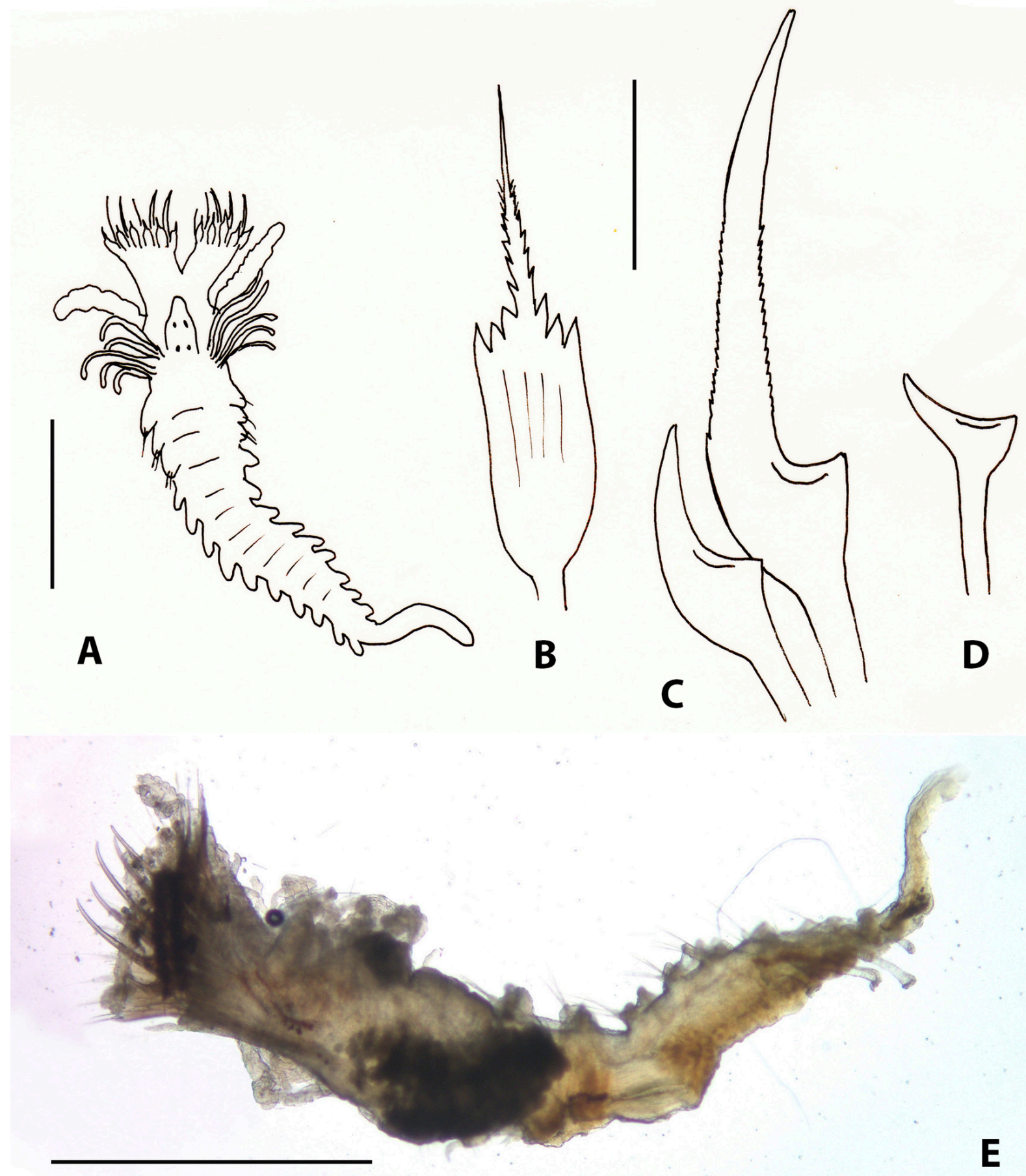

Fig. 10. - Sabellaria spinulos. A, juvenile 40 days after metamorphosis ( 74 days after fertilization) (scale bar $1 \mathrm{~mm}$ ); B, outer paleae (scale bar $100 \mu \mathrm{m}$ ); C, middle paleae (scale bar $100 \mu \mathrm{m}$ ); D, inner palea (scale bar $100 \mu \mathrm{m}$ ); E, photo from 40 days after metamorphosis juvenile (74 days after fertilization) (scale bar $1 \mathrm{~mm}$ ).

ated, abdominal ones having prominent dorsal uncinigerous lobes (Fig. 9A).

The 40-day stage recruit (about two months of life) measured $3 \mathrm{~mm}$ and had 13 abdominal chaetigers and several pairs of feeding tentacles (Fig. 10A, E). The operculum was complete with outer, middle and inner paleae (Fig. 10B, C, D). The outer paleae had a long denticulate distal plume with about 16-20 denticles on each side, a higher number of denticles compared with the adult morphology (Fig. 10B). The middle paleae were geniculate, deeply excavate at the base of the blade, and with a distally erect blade with an inward curving tip. This row included a series of long paleae alternating with a series of short paleae (Fig. 10C, 11A, B). Finally, the inner paleae were geniculate, with blades curving upward from the horizontal plane (Fig. 10D). This pattern was present in all the examined juveniles and observed until the worms reached $3.5 \mathrm{~mm}$ in length, corresponding to about 3 months of life, after which none of the worms survived. At this 

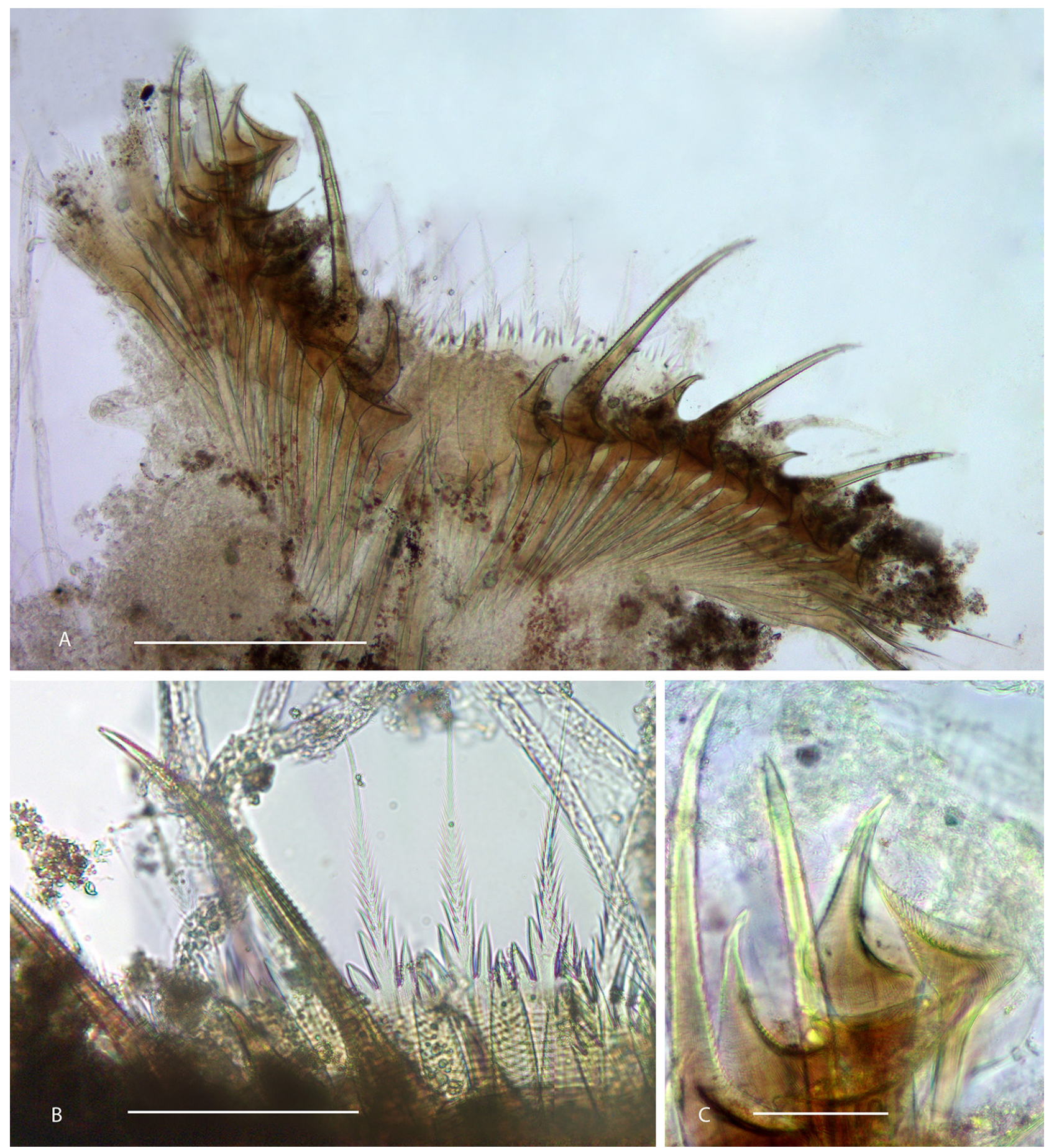

Fig. 11. - Sabellaria spinulosa. A, operculum from 40 days after juvenile metamorphosis showing the pattern of alternating long and short paleae (scale bar $300 \mu \mathrm{m}$ ); B, detail of the middle and outer paleae (scale bar $150 \mu \mathrm{m}$ ); C, detail of an inner palea (scale bar $100 \mu \mathrm{m}$ ).

last stage it was not possible to detect the presence of nuchal spines, though they were always present in the field populations.

Comparing the $3.5 \mathrm{~mm}$ long laboratory recruits with the smallest worms from the field population (4 $\mathrm{mm}$ in length), the latter had the long denticulate distal plume of the outer paleae shorter, with less denticles, similarly to what was observed in adults (fewer than 12 denticles each side) (Fig. 12). Moreover, the middle paleae were less geniculate, as in all adult specimens examined (Fig. 12).
By combining the three-month laboratory worms with the field population, we obtained a more significant correlation between coefficient of variation and size (Fig. 4B). Indeed, the laboratory worms had a higher average coefficient of variation $(0.45 \pm 0.06)$ than any size of field worms.

\section{DISCUSSION}

The present work represents the first formal report of S. spinulosa reefs in the Mediterranean Sea, where, 


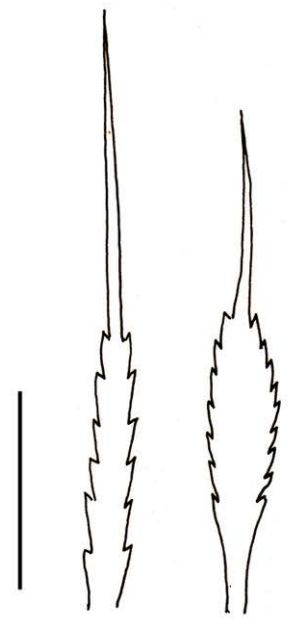

A

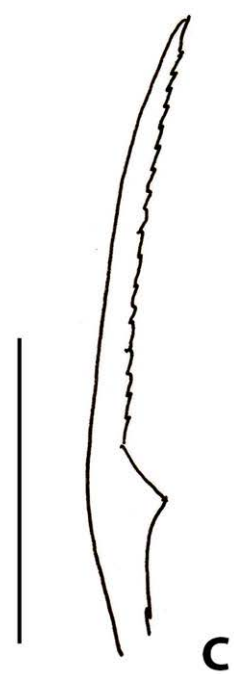

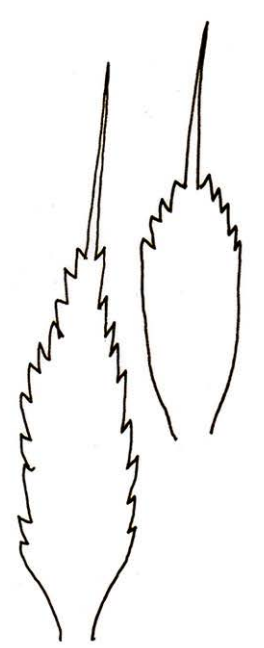

B

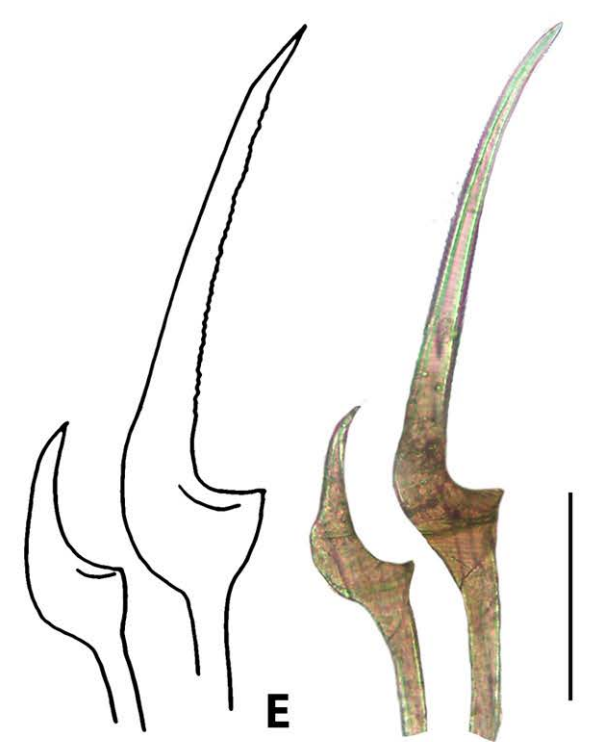

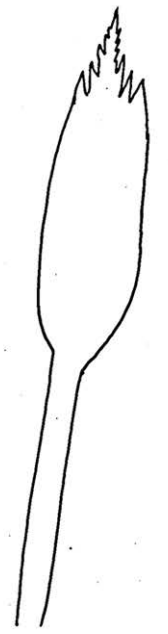

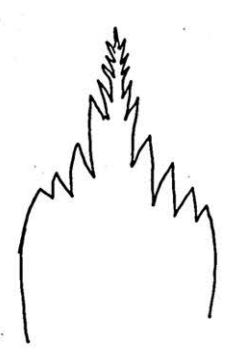

$\mathbf{F}$

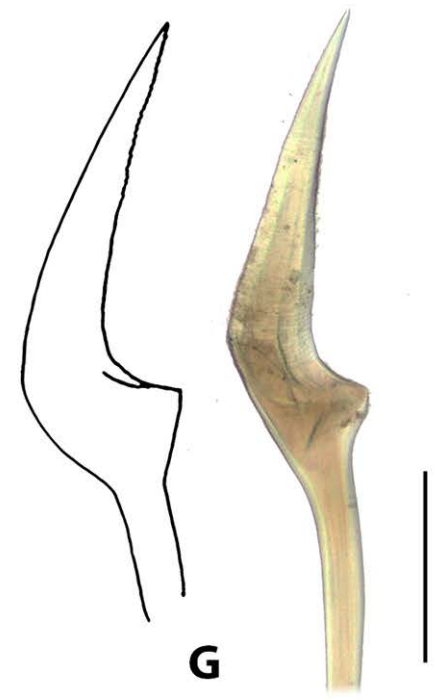

Fig. 12. - Sabellaria spinulosa. Changes in paleae morphology during growth: A, outer palea from a recently metamorphosed specimen (scale bar $20 \mu \mathrm{m}$ ); B-C, outer and middle paleae of a specimen 15 days after metamorphosis (scale bar $100 \mathrm{um}$ ); D-E, outer and middle paleae in a specimen 40 days after metamorphosis (scale bar $150 \mu \mathrm{m}$ ); F-G, outer and middle paleae in a specimen 4 months after metamorphosis (scale bar $300 \mu \mathrm{m})$.

until now, the species was reported as solitary or as forming small clumps (Wilson 1970). These threedimensional biogenic structures are hotspots of biodiversity and are listed as threatened habitats according to the OSPAR Convention (the Convention for the Protection of the Marine Environment of the North-East Atlantic) (Benson et al. 2013) due to their fragility and vulnerability, and we strongly encourage this status to be extended to the Mediterranean reefs.

The reef-building Mediterranean S. spinulosa were ripe in all sampled periods, with a maximum of ripe females in April in all years and in June 2013. Reproduction may therefore extend during the spring-summer period, with females making up $65 \%$ of the population. Considering the state of maturity and the size of individuals within the population, we also agree with Linke (1951) that the species is an annual form reproducing once in its life. Specimens from April 2013 belong to the 2012 generation, which mainly reproduces in spring. This generation possibly continues to grow and reproduce, but with a low survival of their larvae because, according to our experiments, complete development was only attained by the April and June 2013 individuals. Most individuals from October 2013 belonged to a new generation, which was still growing. Though some of them appeared ripe, the eggs were unable to complete development after fertilization and their reproduction could probably be expected in the following April.

The number of eggs for each specimen appears low if compared with S. alveolata (Ayata et al. 2009), in line with its low recruitment (Rees and Dare 1993); this, coupled with the influence of currents for larval retention, could explain the absence of reefs in most of its distributional range, as previously demonstrated for the $S$. alveolata population from the Mont Saint Michel Bay (Ayata et al. 2009). 
The analysis of the opercular structures in the field population showed a great deal of variability, especially in the middle paleae, with alternating and equal-size patterns each present in half of the specimens and lacking correlation with body size. This intrapopulation variability largely covers the differences between $S$. spinulosa and $S$. spinulosa alcocki, thus preventing the erection of several varieties within $S$. spinulosa. We therefore hypothesize that the varieties were erected in the past based on a few specimens.

Larval development of S. spinulosa is here described for the first time for a Mediterranean population, allowing a comparison with the non-Mediterranean studies. Regarding the egg diameter, we found $100 \mu \mathrm{m}$ against $50 \mu \mathrm{m}$ by Pearce et al. (2011) and $150 \mu \mathrm{m}$ by Wilson (1929). Developmental time was also different: we found only 2 weeks of pelagic development against 4 weeks found by Pearce et al. (2011) and 6-8 weeks by Wilson (1929). By contrast, our data on developmental time are similar to those observed experimentally for other species: S. alveolata and Phragmatopoma californica (Fewkes, 1889) (Cazaux 1964, Pawlik 1988). However, egg size estimates could be influenced by operational procedures, while growth rate and settlement time of sabellariid larvae under laboratory conditions can be greatly influenced by the culture technique (Eckelbarger 1977). For example, the long developments recorded for S. alveolata and S. spinulosa (up to 32 weeks in the former) are probably not representative of the species in nature (Wilson 1970), while the early settlement at 6 weeks experimentally recorded by Wilson (1929) most likely represents the real field time. Thus, caution must be taken when comparing laboratory and field larval development times.

In our study, the development of S. spinulosa seems to be influenced by the temperature only during the pelagic stages, with a faster growth at $21^{\circ} \mathrm{C}$. However, after settlement, specimens from this treatment delayed metamorphosis by about 8 days compared with those reared at $14^{\circ} \mathrm{C}$, so no difference in the total developmental time could be identified. By contrast, a delay in metamorphosis of about 10 days has been experimentally demonstrated for S. vulgaris (Eckelbarger 1975) and P. californica (Eckelbarger 1977).

Mortality during the pelagic life in laboratory conditions was not specifically measured, but it seems to be higher during settlement, as previously observed in experimental conditions (Wilson 1929, Cazaux 1964, Eckelbarger 1975), where it seems to depend on the presence of stirring and available sand. During settlement, only some degree of gregariousness characterizing other sabellarian species (Pawlik 1988) was observed. However, the lack of gregarious behaviour could also be due to the particular rearing conditions in our experiments.

Morphological changes in larval development of S. spinulosa specimens from the Mediterranean are largely indistinguishable not only from non-Mediterranean S. spinulosa populations, but also from those described in other sabellariids (Wilson 1929, $1968 \mathrm{a}, \mathrm{b}$, Hartman 1944, Dales 1952, Cazaux 1964, Eckelbarger 1975), confirming a noteworthy similarity overall. As observed by Wilson (1929), the early developmental stages of S. spinulosa and S. alveolata are indistinguishable. These two species become easily distinguishable only when the adult primary opercular paleae appear among the long provisional bristles of the first parapodia. As already pointed out, however, during opercular formation settling chaetae or "primary paleae" are lost and replaced by "secondary paleae" showing the final adult shape (Wilson 1929, Eckelbarger 1975). We also observed marked ontogenetic changes during the post-settlement period, with several different forms of each palea type present within the juvenile operculum, which become progressively more adult-like as paleae are lost and replaced. Consequently, in juvenile S. spinulosa the length of the denticulate distal plume in outer paleae and the shape and length of the middle paleae are similar to those in S. alcocki. As in the case of $S$. alveolata, $S$. alcocki becomes easily distinguishable from $S$. spinulosa only when the operculum achieves the adult features.

Data obtained from laboratory rearing combined with observations from a field population led us to hypothesize that the final opercular configuration was achieved when the worm is about $4 \mathrm{~mm}$ long. Thus, the records of $S$. alcocki in the Mediterranean area could be partially attributed to the examination of S. sрinulosa specimens at different stages of development. Therefore, we strongly support the hypothesis that $\mathrm{Sa}$ bellaria alcocki is not present in the Mediterranean and that special care must be taken in identifying small or young individuals of $S$. spinulosa. Particular attention must be addressed to the presence of nuchal spines, as the young specimens lacking these spines closely resemble $S$. alcocki both in the outer denticulate distal plume of the outer paleae and in the shape of the middle paleae.

\section{ACKNOWLEDGEMENTS}

Financial support was provided by the MIUR (PRIN project). The authors acknowledge the support by the MARBEF network of excellence "Marine Biodiversity and Ecosystem Functioning" funded in the EU Sixth Framework Programme (contract no. GOCE-CT-2003-505446).

\section{REFERENCES}

Achary G.P.K. 1974. Polychaetes of the family Sabellariidae with special reference to their intertidal habitat. Proc. Indian Natl. Sci. Acad. 38: 442-455.

Ayata S.D., Ellienc C., Dumas F., et al. 2009. Modelling larval dispersal and settlement of the reef-building polychaete Sabellaria alveolata: Role of hydroclimatic processes on the sustainability of biogenic reefs. Cont. Shelf Res. 29: 1605-1623. http://dx.doi.org/10.1016/j.csr.2009.05.002

Benson A., Foster-Smith B., Gubbay S., et al. 2013. Background Document for Sabellaria spinulosa reefs. OSPAR's vision of a clean, healthy and biological diverse North-east Atlantic used sustainably. OSPAR Commission Report. Publication Number: 614/2013: 1-24

Capa M., Hutchings P., Peart R. 2012. Systematic revision of Sabellariidae (Polychaeta) and their relationships with other polychaetes using morphological and DNA sequence data. Zool. J. Lin. Soc. 164: 245-284.

http://dx.doi.org/10.1111/j.1096-3642.2011.00767.x 
Castelli A., Bianchi C.N., Cantone G., et al. 2008. Annelida Polychaeta. In: Checklist della flora e della fauna dei mari italiani. Biol. Mar. Medierr. 15(supp. 1): 323-373.

Cazaux C. 1964. Developpement larvaire de Sabellaria alveolata (Linné). Bull. Inst. Oceanogr. (Monaco), 62: 1-15.

Çinar M.E., Katagan T., Öztürk B., et al. 2006. Temporal changes of soft-bottom zoobenthic communities in and around Alsancak Harbor (Izmir Bay, Aegean Sea), with special attention to the autecology of exotic species. Mar. Ecol., 27(3): 229-246. http://dx.doi.org/10.1111/j.1439-0485.2006.00102.x

Çinar M. E., Katağan, T., Koçak, F., et al. 2008. Faunal assemblages of the mussel Mytilus galloprovincialis in and around Alsancak Harbour (Izmir Bay, eastern Mediterranean) with special emphasis on alien species. J. Mar. Syst. 71(1): 1-17. http://dx.doi.org/10.1016/j.jmarsys.2007.05.004

Coll M, Piroddi C, Kaschner K, et al. 2010. The biodiversity of the Mediterranean Sea: Estimates, patterns, and threats. PLoS ONE 5(8): e11842. http://dx.doi.org/10.1371/journal pone.0011842

Dales R.P. 1952. The development and structure of the anterior region of the body in the Sabellariidae, with special reference to Phragmatopoma californica. Q. J. Microsc. Sci. 93: 435-452.

Dauvin J.C. 1997. Les biocenoses marines et littorales francaises des cotes atlantique, Manche et Mer du Nord. Syntesi, menance et prospective, $376 \mathrm{pp}$. Service du Patrimoine Naturel/IEGM/ MNHN, Paris.

Dubois S., Christian R., Frédéric O. 2002. Biodiversity associated with Sabellaria alveolata (Polychaeta: Sabellariidae) reefs: effects of human disturbances. J. Mar. Biol. Ass. U. K. 82: $817-826$ http://dx.doi.org/10.1017/S0025315402006185

Eckelbarger K.J. 1975. Developmental studies of the post-settling stages of Sabellaria vulgaris (Polychaeta: Sabellariidae). Mar. Biol. 30: 137-149. http://dx.doi.org/10.1007/BF00391588

Eckelbarger K.J. 1977. Larval development of Sabellaria floridensis from Florida and Phragmatopoma californica from southern California (Polychaeta: Sabellariidae), with a key to the sabellariid larvae of Florida and a review of development in the family. Bull. Mar. Sci. 27(2): 241-255.

Fauchald K. 1977. Polychaetes from intertidal areas in Panama, with a review of previous shallow-water records. Smithsonian Contrib. Zool. 221: 1-81. http://dx.doi.org/10.5479/si.00810282.221

Fauchald K., Bellan G. 2013. Sabellaria alcocki Gravier, 1906. In: Read G., Fauchald K. (eds) World Polychaeta database. Accessed on 2014-02-11 through: World Register of Marine Species at http://www.marinespecies.org/aphia.php?p=taxdetails\&id=130865

Fauvel P. 1914. Annélides Polychètes de San Thomé (Golfe de Guinée) receuillies par M. Ch. Gravier. Arch. Zool. Expér. Génér. 54(5): 105-155

Fauvel P. 1927. Polychètes sédentaires. Addenda aux errantes, arachiannélides, myzostomaires. Faune de France 16. Paul Lechevalier, Paris, 494 pp.

Gravier C. 1906. Un Sabellarien vivant sur un Brachiopode (Kingenia alcocki Joubin). Bull. Mus. Natl. Hist. Nat. Paris 12: 540-543.

Gruet Y. 1982. Recherches sur l'écologie des récifs d'Hermelles édicés par l'anneélide polychète Sabellaria alveolata (Linné). $\mathrm{PhD}$ thesis, Université des Sciences et Techniques, Nantes, France.

Gruet Y. 1986. Spatio-temporal changes of sabellarian reefs built by the sedentary polychaete Sabellaria alveolata (Linné). Mar. Ecol.-PSZNI 7: 303-319.

http://dx.doi.org/10.1111/j.1439-0485.1986.tb00166.x

Hartman O. 1944. Polychaetous Annelids. PartVI. Paraonidae, Ma- gelonidae, Longosomidae, Ctenodrillidae, and Sabellariidae. Alan Hancock Pacif. Exped. 10: 311-389.

Hutchings P., Capa M., Peart R. 2012. Revision of the Australian Sabellariidae (Polychaeta) and description of eight new species. Zootaxa, 3306: 1-60.

Jones L.A., Hiscock K., Connor D.W. 2000. Marine habitat reviews. A summary of ecological requirements and sensitivity characteristics for the conservation and management of marine SACs. Joint Nature Conservation Committee, Peterborough. (UK Marine SACs Project report).

Kirtley D.W. 1994. A review and taxonomic revision of the family Sabellariidae Johnston, 1865 (Annelida; Polychaeta). Sabecon Press, Science Series Number 1, pp 223.

La Porta B., Nicoletti L. 2009. Sabellaria alveolata (Linnaeus) reefs in the central Tyrrhenian Sea (Italy) and associated polychaete fauna. Zoosymposia 2: 527-536.

Leuckart R. 1849. Zur Kenntnis der Fauna von Island. Arch. Natur. 15(1): 149-208

Linke O. 1951. Neue Beobachtungen uber Sandkorallen-Riffe in der Nordsee. Natur und Volk 81: 77-84.

Nishi E., Bailey-Brock J.H., Dos Santos A.S., et al. 2010. Sabellaria isumiensis n. sp. (Annelida: Polychaeta: Sabellariidae) from shallow waters off Onjuku, Boso Peninsula, Japan, and re-descriptions of three Indo-West Pacific sabellariid species. Zootaxa, 2680: 1-25.

Parapar J., Besteiro C., Urgorri V. 1992. Nuevas aportaciones al conocimiento de los anélidos poliquetos en el litoral gallego (N.O. Península Ibérica). NACC Bioloxía, 3: 109-123.

Pawlik J.R., 1988. Larval settlement and metamorphosis of two gregarious sabellariid polychaetes: Sabellaria alveolata compared with Pragmatopoma californica. J. Mar. Biol. Ass. U. K. 68: 101-124. http://dx.doi.org/10.1017/S002531540005013X

Pearce B., Hill J.M., Grubb L., et al. 2011. Impacts of marine aggregate dredging on adjacent Sabellaria spinulosa aggregations and other benthic fauna. Marine Aggregates Levy Sustainability Fund MEPF 08/P39 and The Crown Estate. Marine Ecological Surveys Limited, 3 Palace Yard Mews, BATH, BA1 2NH. 35 pp.

Porras R., Bataller J.V., Murgui E., et al. 1996. Trophic structure and community composition of polychaetes inhabiting some Sabellaria alveolata (L.) reefs along the Valentia Gulf coast, western Mediterranean. Mar. Ecol. 17(4): 583-602. http://dx.doi.org/10.1111/j.1439-0485.1996.tb00419.x

Read G. 2014. Sabellaria spinulosa (Leuckart, 1849). In: Read G., Fauchald K. (eds), World Polychaeta database. Accessed on 2014-07-09, through: World Register of Marine Species at http://www.marinespecies.org/aphia.php?p=taxdetails\&id=130867

Rees H.L., Dare P.T. 1993. Sources of mortality and associated life-cycle traits of selected benthic species: a review. Fisheries Research Data Report Number 33.

Wilson D.P. 1929. The larvae of the British sabellarians. J. Mar. Biol. Ass. U. K. 16: 221-269. http://dx.doi.org/10.1017/S0025315400029787

Wilson D.P. 1968a. The settlement behaviour of the larvae of Sabellaria alveolata (L.). J. Mar. Biol. Ass. U.K. 48: 387-435. http://dx.doi.org/10.1017/S0025315400034561

Wilson D.P. 1968b. Some aspects of the development of eggs and larvae of Sabellaria alveolata (L.). J. Mar. Biol. Ass. U. K. 48: 367-386. http://dx.doi.org/10.1017/S002531540003455X

Wilson D.P. 1970. The larvae of Sabellaria spinulosa and their settlement behaviour. J. Mar. Biol. Ass. U. K. 50: 33-52. http://dx.doi.org/10.1017/S0025315400000588

Wilson D.P. 1971. Sabellaria colonies at Duckpool, North Cornwall, 1961-1970. J. Mar. Biol. Ass. U. K. 51: 509-580. http://dx.doi.org/10.1017/S002531540001496X 